\title{
SENSOR SYSTEM DESIGN FOR PROPELLER TEST BENCH
}

\author{
M. Nurul Ihsan ${ }^{1}$, Denny Dermawan ${ }^{2}$, Lazuardy Rahendra $P^{3}$ \\ 1,2,3 Teknik Dirgantara, Institut Teknologi Dirgantara Adisutjipto \\ mnihsan27@gmail.com, lazuardyrp@itda.ac.id,
}

\begin{abstract}
The sensor system is a system that functions to detect signals that come from changes in energy such as electrical energy, physical energy, chemical energy, biological energy, mechanical energy, and so on. The propeller test bench is an propeller performance testing platform prior to propeller installation on an aircraft to ensure engine suitability. The purpose of this design is to test the performance capability of the engine with the right sensor system measurement tool so that it can generate the value of thrust, rpm speed, and the temperature of an engine which will be designed to be used in the learning process to support propulsion practicum activities. The method used in this research is an experimental method of sensor system design. The design of the sensor system consists of a tachometer as a rpm measurement sensor, a thermostat as a sensor to measure the temperature of the propeller spool and temperature of the engine fin, and also a load cell as a sensor to measure the thrust value.The sensor system test results were then validated using the measurement results by the sensor manufacturer. The test was carried out on a wood-type propeller measuring $22 \times 8$ chords 4,5 $\mathrm{cm}$ and $5 \mathrm{~cm}$. Based on the test results, it is known that the chord wood type propeller is 4,5 $\mathrm{cm}$, at the maximum rpm is 7021.7, the resulting thrust value is 6.75 . In testing the $5 \mathrm{~cm}$ chord wood type propeller shows the maximum speed of 6977.5 produces a thrust of 6.95. Validation was carried out on the measurement results of rpm and thrust, the average error factor obtained for 4,5 cm chord wood type propeller was $0.783 \%$, while for $5 \mathrm{~cm}$ chord wood type propeller the average error factor obtained was $1.0582 \%$. From the resulting average error, it can be concluded that the measuring instrument for this sensor system has good accuracy.
\end{abstract}

Keywords: Propeller Test Bench, Tachometer, Thermostat, Load cell, and Arduino UNO.

\section{Pendahuluan}

Propeller test bench merupakan sebuah platform pengujian performa propeller sebelum dilakukannya pemasangan pada pesawat untuk memastikan kelayakan propeller. Pengujian dilakukan untuk mengembangkan produk baru dari penelitian ekperimental di industri manufaktur seperti pesawat dan drone. . ${ }^{[1][2] ~ P e n g u j i a n ~ p e r f o r m a ~ p a d a ~ p r o p e l l e r ~ t e s t ~ b e n c h ~}$ terdiri dari pengujian untuk rpm, torsi, dan gaya dorong. Penelitian ini membahas mengenai perancangan sistem sensor untuk pengujian propeller test bench. Rancangan alat ukur ini terdiri dari sensor rpm, sensor suhu pada engine fin, sensor suhu pada spool propeller, dan sensor thrust menggunakan load cell (strain gauge) yang ditampilkan pada display box. $.^{[3][4]} .^{[5]}$ Penelitian ini merupakan pengembangan dari penelitian sebelumnya yang dilakukan oleh LAPAN (2018), namun hal yang membedakannya adalah pemilihan propeller dan juga perameter yang diukur. Tujuan dilakukan perancangan ini, yaitu untuk menguji performa dari propeller dengan alat ukur sistem sensor yang terdiri dari pengukuran nilai thrust atau daya dorong, kecepatan rpm, dan suhu dari engine. . ${ }^{[6][7]}$ Secara garis besar, pembuatan sistem sensor ini bertujuan untuk meminimaslisir terjadinya kecelakaan kerja selama dilakukannya pengujian. Sistem sensor ini diharapkan dapat digunakan sebagai penunjang proses pembelajaran dalam kegiatan praktikum propulsi khususnya di kampus Institut Teknologi Dirgantara Adisutjipto (ITDA). . ${ }^{[8]}$ 


\section{Metodologi Penelitian}

\section{a. Objek Penelitian}

Objek pada penelitian ini adalah Engine DLE 55 CC Single Cylinder Petrol, dengan tujuan untuk mengukur performa engine untuk mengetahui nilai thrust engine, temperature spool propeller, dan temperature engine fin. . ${ }^{[9][10][11]}$ Spesifkasi dari engine ini adalah sebagai berikut:

Tabel 1. Spesifikasi engine DLE-55RA 55CC

\begin{tabular}{|l|l|}
\hline Displacement & $55.6 \mathrm{CC} / 3.4 \mathrm{cu}$ in \\
\hline Bore & $1.77 \mathrm{in} / 45 \mathrm{~mm}$ \\
\hline Stroke & $1.38 \mathrm{in} / 35 \mathrm{~mm}$ \\
\hline RPM range & $1.350-7.500$ \\
\hline \multirow{2}{*}{ Output } & $5.5 \mathrm{hp} / 8.500 \mathrm{rpm}$ \\
\hline \multirow{3}{*}{ Weight } & $1330 \mathrm{~g} / 46.91 \mathrm{oz}$ (engine) \\
\cline { 2 - 2 } & $90 \mathrm{~g} / 3.17 \mathrm{oz}$ (muffler) \\
\cline { 2 - 2 } & $130 \mathrm{~g} / 4.58 \mathrm{oz}$ (ignition) \\
\hline
\end{tabular}

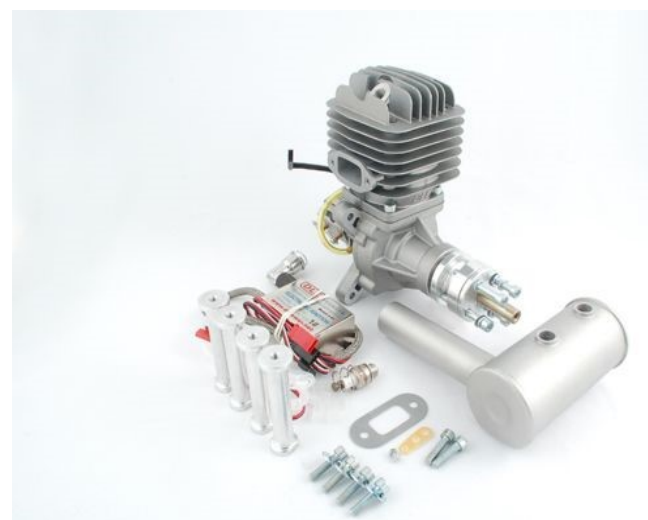

Gambar 1. Engine DLE 55 CC Single Cylinder Petrol

\section{b. Propeller Uji}

Objek penelitian sistem sensor ini juga dilakukan pada propeller tipe kayu dengan ukuran 22 × 8 chord $4,5 \mathrm{~cm}$ dan ukuran $22 \times 8$ chord $5 \mathrm{~cm}$. Tujuan pengujian ini adalah untuk mengetahui nilai rpm dari propeller dengan kecepatan minimum saat pengujian sebesar $1.500 \mathrm{rpm}$ dan kecepatan maksimum sebesar $7.500 \mathrm{rpm}$.

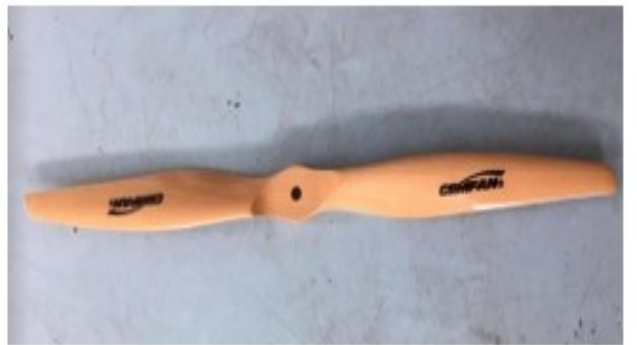

Gambar 2. Propeller Tipe kayu 22 × 8 Chord : $4,5 \mathrm{~cm}$

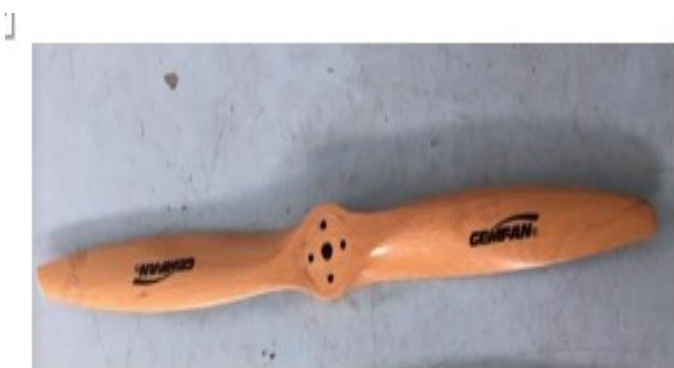

Gambar 3. Propeller Tipe Kayu 22 × 8 Chord: $5 \mathrm{~cm}$ 


\section{c. Perancangan Sistem Sensor}

Konsep awal perancangan sistem sensor dimulai dengan perancangan display box yang dilakukan dengan software CATIA V5. Display box dibuat menggunakan akrilik dengan ketebalan $5 \mathrm{~mm}$ dengan ukuran $30 \mathrm{~cm}$ x $23 \mathrm{~cm} \times 10 \mathrm{~cm}$.

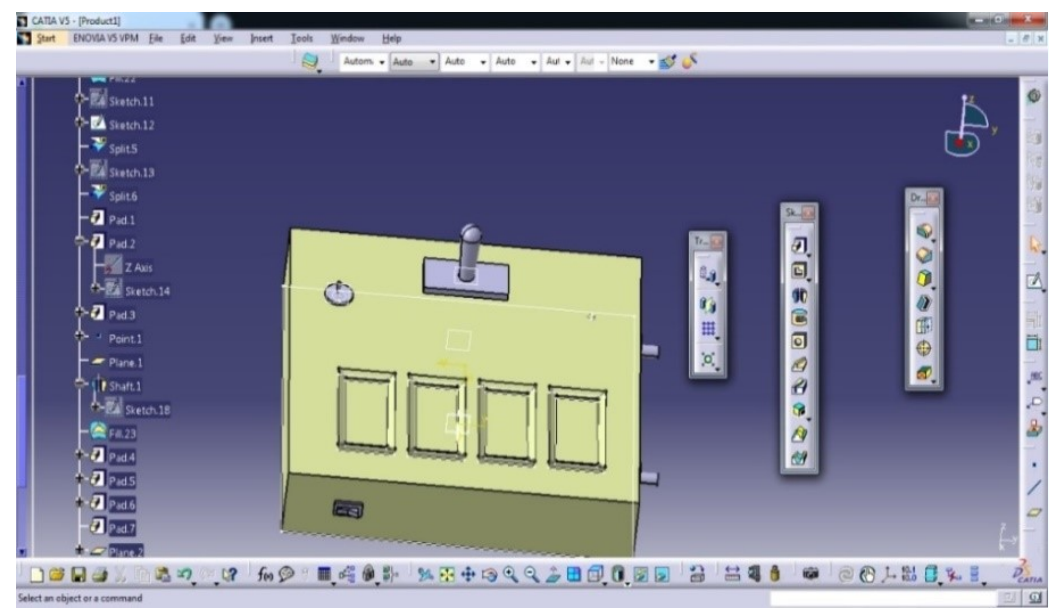

Gambar 4. Desain Awal Display box Sistem Sensor pada CATIA V5

Rancangan sistem sensor ditampilkan dengan block diagram yang berfungsi untuk memberikan gambaran dari sistem atau program yang masing-masing fungsinya diwakili oleh gambar kotak berlabel, dan hubungan diantaranya digambarkan oleh garis penghubung.

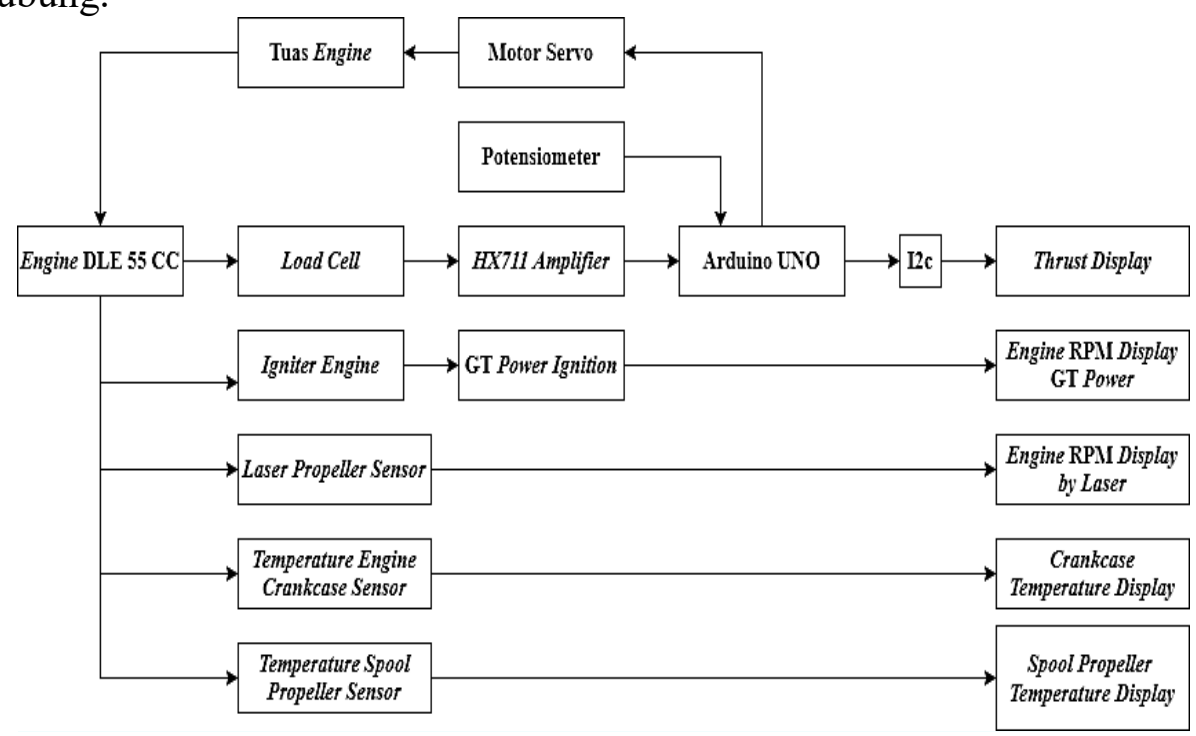

Gambar 5. Block Diagram Sistem Sensor

\section{d. Perancangan Parameter Thrust}

Komponen yang digunakan pada perancangan parameter thrust terdiri dari load cell, HX711, Arduino UNO, modul I2c, dan LCD 16 × 2 dihubungkan dengan kabel jumper dengan warna dan fungsi yang berbeda. 


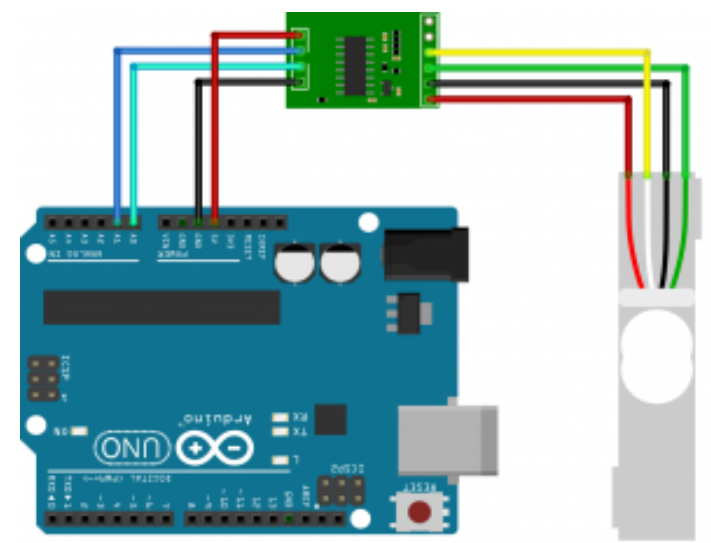

Gambar 6. Rangkaian Arduino dengan Load cell

\begin{tabular}{|c|c|c|}
\hline No. & Pin Arduino & Pin Hx711 \\
\hline 1. & $5 \mathrm{~V}$ & VCC \\
\hline 2. & GND & GND \\
\hline 3. & 4 & DT \\
\hline 4. & 5 & SCK \\
\hline
\end{tabular}

\section{e. Perancangan Parameter Engine RPM by Laser}

Perancangan parameter engine rpm by laser dapat dilihat pada Schematic diagram pada Gambar 7. Sensor ini menggunakan digital tachometer dengan prinsip kerja menembakan cahaya laser menuju objek yang diukur dengan transmitter sebagai pengantarnya dan receiver sebagai penerima pantulan cahaya laser tersebut. Putaran propeller yang diukur akan ditampilkan nilainya pada display engine rpm yang terdapat pada display box.

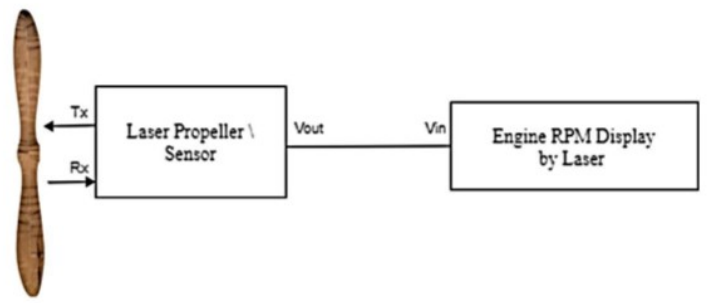

Gambar 7. Schematic Diagram Parameter Engine RPM by Laser

\section{f. Perancangan Parameter Engine RPM by GT Power}

Block diagram parameter engine rpm by gt power dapat dilihat pada schematic diagram Gambar 8. Sensor ini menjelaskan rangkaian engine dengan GT Power Ignition. Sensor GT Power Ignition terpasang di spool propeller yang berfungsi untuk mengukur nilai RPM dari spool propeller, terhubung melalui igniter engine. Hasil pengukuran rpm akan ditampilkan pada engine RPM display GT Power yang terletak pada display box.

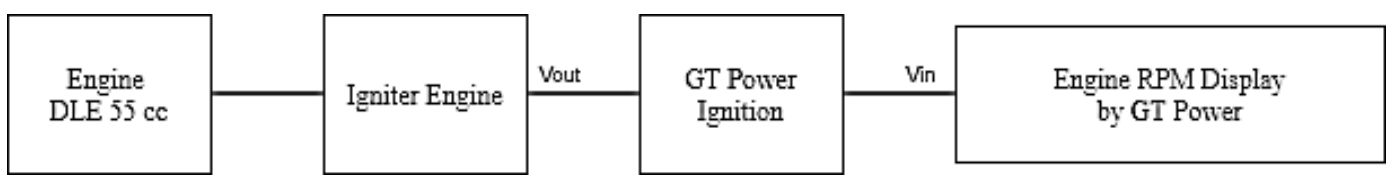

Gambar 8. Block Diagram Parameter Engine RPM by GT Power 


\section{g. Perancangan Parameter Speed Engine}

Block diagram perancangan parameter speed engine dapat dilihat pada Gambar 9. Hal ini dibuat untuk mempermudah pembacaan rangkaian engine dengan potensiometer, Arduino UNO dan motor servo. Tuas engine (throttle) untuk mengatur kecepatan engine diatur oleh motor servo yang terhubung dengan push rod, motor servo di program pada arduino yang dihubungkan dengan potensiometer untuk mengatur kecepatan dari engine tersebut.

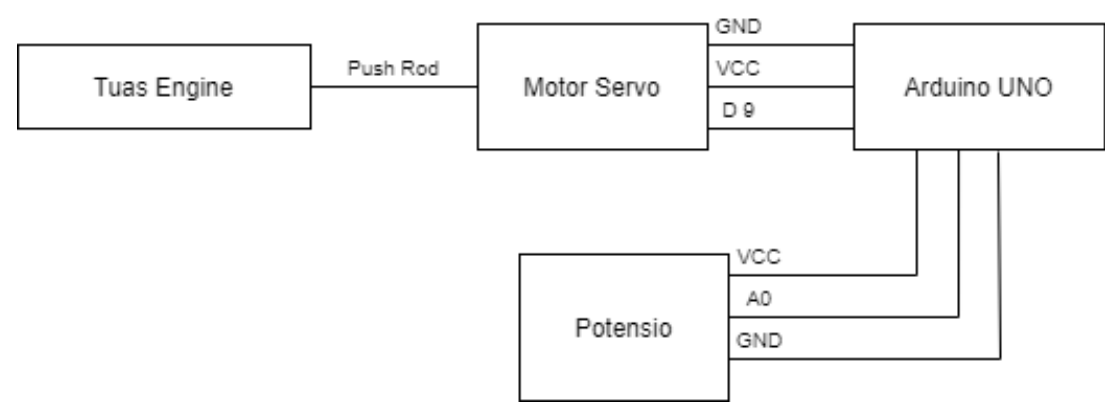

Gambar 9. Schematic Diagram Parameter Speed Engine

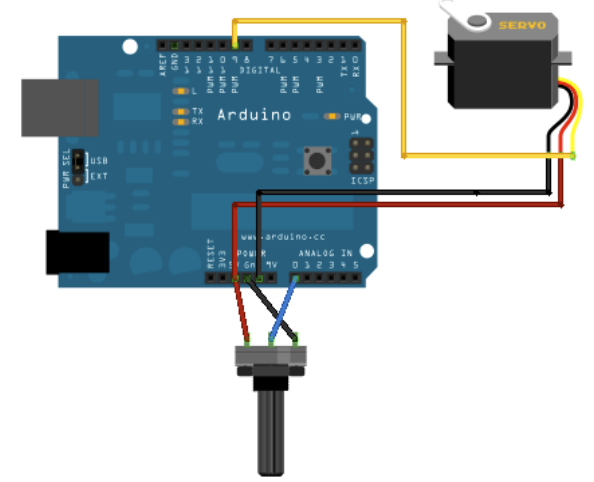

Gambar 10. Rangkaian Arduino dengan Potensiometer

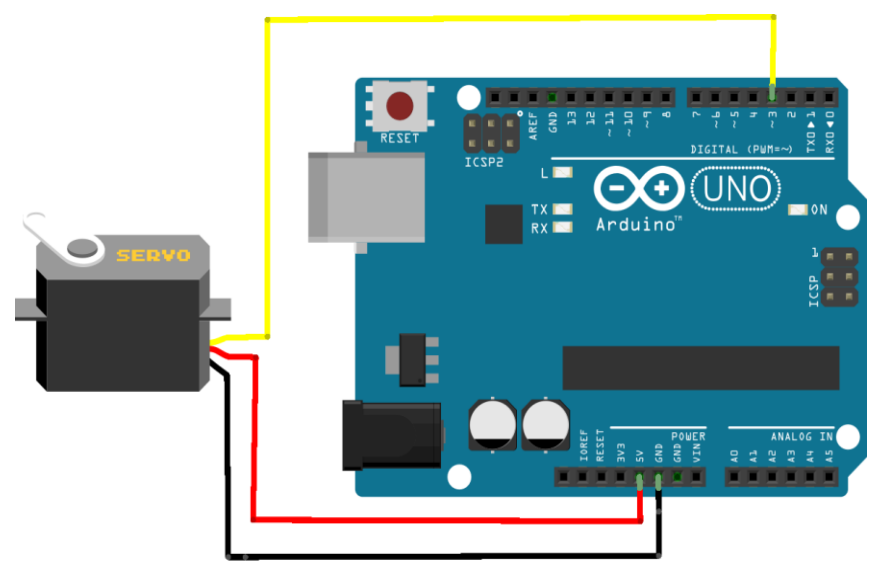

Gambar 11. Rangkaian Arduino dengan Servo

\section{h. Pemrograman pada Arduino UNO}

Pemrograman pada Arduino UNO dilakukan menggunakan software Arduino IDE (Integrated Development Environment) yang bersifat open source. Arduino IDE berfungsi sebagai editor program yang memungkinkan membuat, mengedit dan memvalidasi kode program. 


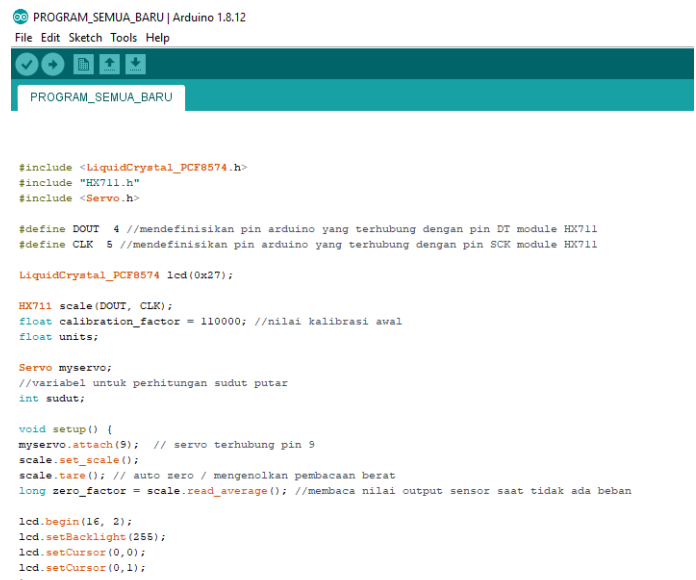

Gambar 12. Script program pada Arduino IDE

\section{i. Perancangan Hardware}

Pembuatan sistem sensor pada engine test bed berfungsi untuk mengetahui performa dari engine tersebut. Langkah awal yang dilakukan adalah merakit komponen utama, seperti LCD (Liquid Crystal Display) 16 x 2, thermostat, digital tachometer, potensiometer, motor servo, dan load cell yang dihubungkan dengan Arduino UNO. Apabila semua sensor telah dirangkai dengan Arduino UNO, komponen selanjutnya dipasang pada display box..$^{[12][13]}$ Pengukuran thrust dilakukan menggunakan sensor load cell dengan kapasitas maksimal pengukuran hingga $20 \mathrm{~kg}$. Sensor ini ditempatkan sejajar dengan dudukan engine pada meja uji agar hasil pengukuran thrust engine yang didapat maksimal.

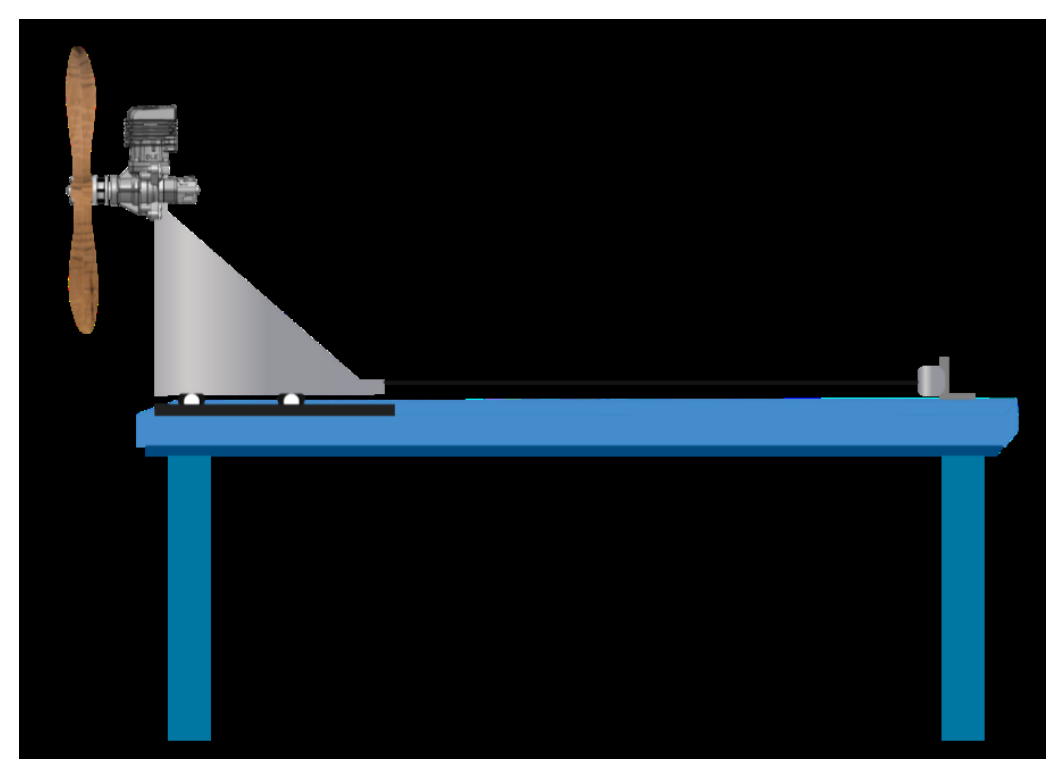

Gambar 13. Posisi Load Cell pada Meja Uji

Sensor tachometer diitunjukkan pada Gambar 14. sensor ini diletakkan di bagian pinggir dudukan engine test bed, sensor ini terhubung dengan PCB konektor 4 pin yang telah dibuat, dan dihubungkan lagi ke display box menggunakan kabel telpon. 


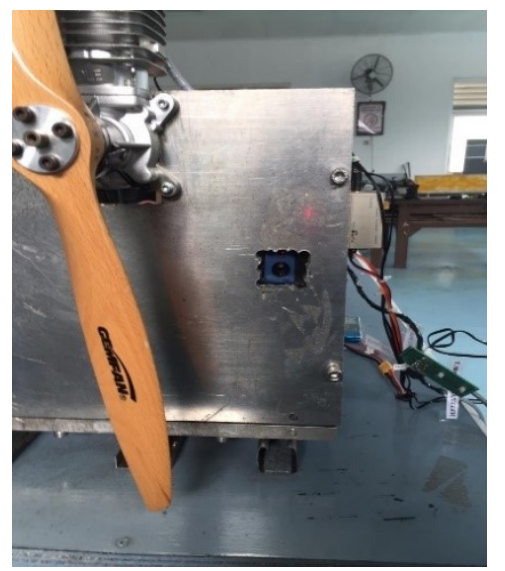

Gambar 14. Posisi Penempatan Sensor Tachometer

Thermostat diletakkan pada engine fin dan spool propeller yang dapat dilihat pada Gambar 15 dan 16. Penempatan thermostat pada engine fin dilakukan dengan menambahkan blok aluminium sehingga thermostat tidak berpindah dari posisi semula. Pada spool propeller, thermostat diletakkan pada bagian depan spool yang dekat dengan propeller menggunakan pipa letter $\mathrm{U}$.

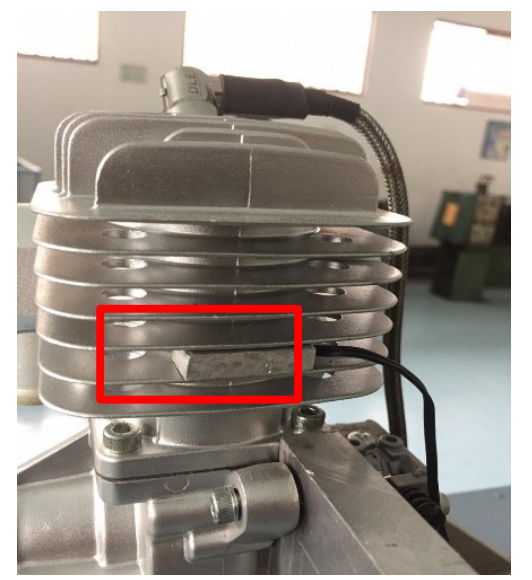

Gambar 15. Thermostat pada engine fin

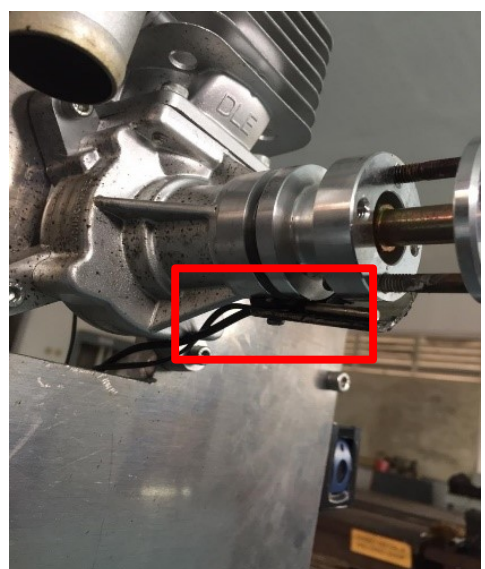

Gambar 16. Thermostat pada spool propeller

Motor servo diletakkan pada blok aluminium yang dapat dilihat pada Gambar 17. Sensor ini terhubung dengan push rod yang berfungsi untuk menggerakkan tuas engine yang telah diatur pada sudut $0^{\circ}$ sampai $180^{\circ}$.

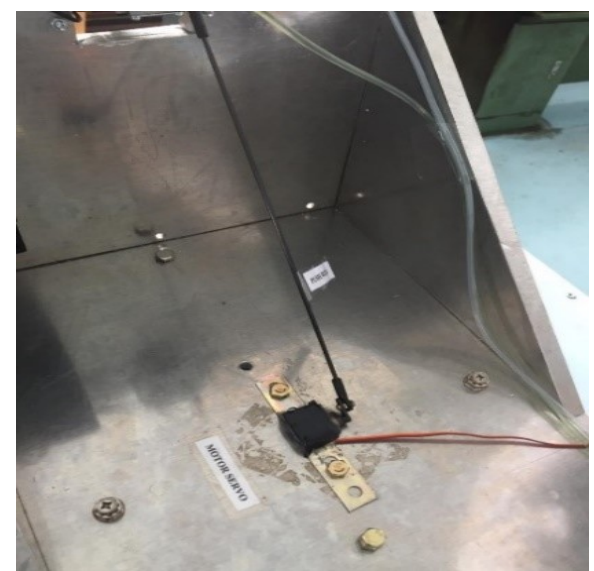

Gambar 17. Penempatan Motor servo Mini 


\section{j. $\quad$ Metode Pengumpulan dan Pengolahan Data}

Pengujian diawali dengan menghidupkan engine, dengan cara memutar propeller secara manual searah jarum jam, bersamaan dengan mengatur potensio untuk menarik tuas engine yang terhubung dengan motor servo dan push rod. Kemudian, ketika engine menyala dilakukan pengamatan untuk mendapatkan nilai rpm, thrust, temperatur spool propeller dan temperature engine fin pada posisi idle, dan full throttle. Penelitian dilakukan dengan dua metode yaitu, pertama perhitungan secara teoritis menggunakan Microsoft Excel dengan memasukkan beberapa rumus yang akan dihitung, dan kedua melakukan pengujian statik. Perhitungan dengan Microsoft Excel dilakukan dengan membandingkan besarnya gaya dorong yang diperoleh pada saat pengujian. Pengujian dilakukan pada propeller dua bilah tipe kayu dengan ukuran masing-masing propeller 22 x 8 chord $5 \mathrm{~cm}$ dan $22 \times 8$ chord $4,5 \mathrm{~cm}$.Nilai thrust yang terukur, dihitung dengan menggunakan software Static Thrust Calculator. Software ini digunakan untuk memvalidasi hasil pengukuran thrust antara sensor yang telah dirancang dengan Static Thrust Calculator. Perhitungan nilai thrust didasarkan pada spesifikasi dari propeller yang digunakan serta nilai rpm yang terukur.

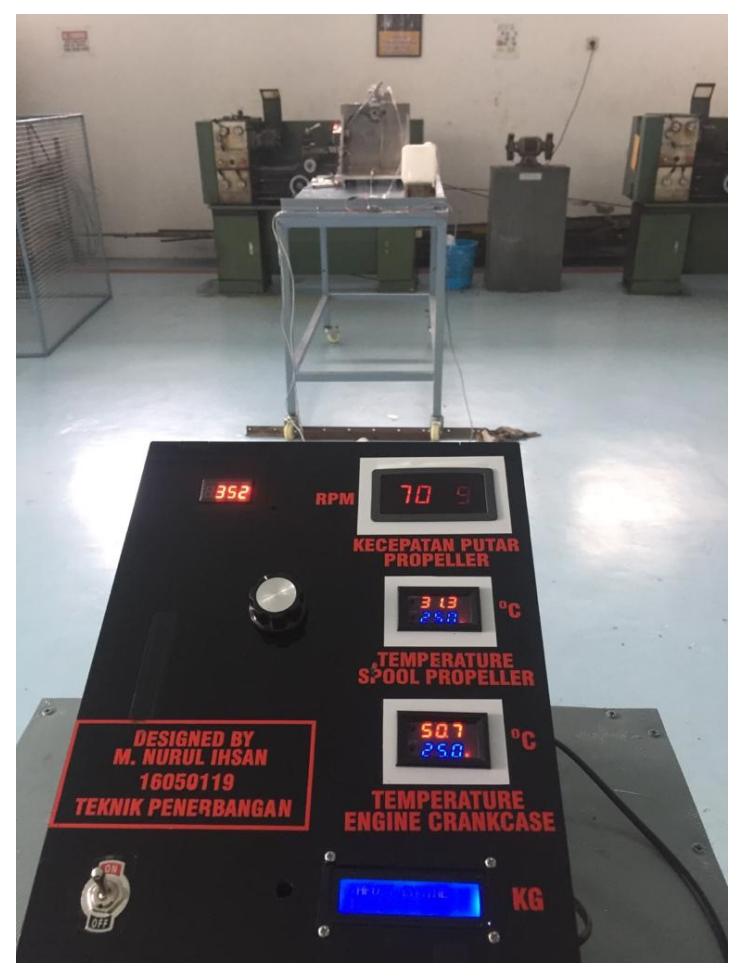

Gambar 18. Proses Percobaan Pengujian pada Propeller Test Bench 


\section{Hasil Dan Pembahasan}

a. Hasil Pengujian Propeller Tipe Kayu $22 \times 8$ Chord $4,5 \mathrm{~cm}$

Pengujian pada propeller tipe kayu 22 × 8 chord $4,5 \mathrm{~cm}$ dilakukan sebanyak tiga kali pengulangan. Jika dibuat grafik perbandingan, maka akan terlihat perbedaan antara nilai thrust dengan rpm pada propeller tipe kayu chord $4,5 \mathrm{~cm}$. Grafik perbandingan tersebut dapat dilihat pada Gambar 20.

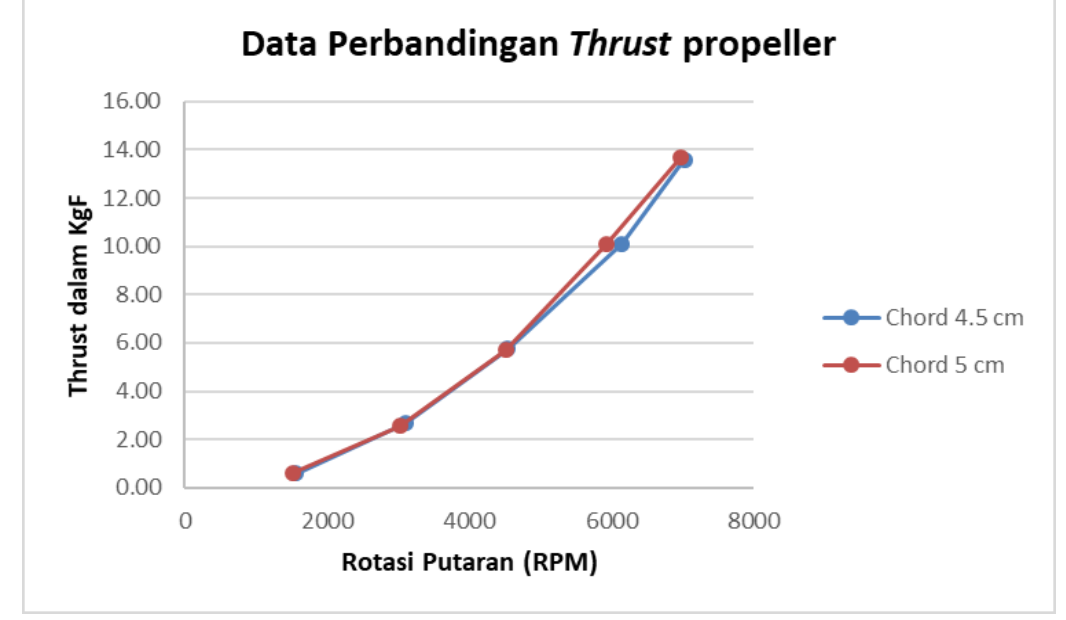

Gambar 20. Grafik Perbandingan Thrust dengan RPM pada Chord 4,5 cm

Berdasarkan grafik data perbandingan antara thrust dan rpm (Gambar 20), dapat diketahui bahwa sensor tachometer laser membaca nilai rpm dari propeller pada kecepatan minimum $1500 \mathrm{rpm}$ menghasilkan nilai thrust sebesar $0,65 \mathrm{KgF}$, sedangkan pada kecepatan maksimum yaitu $7000 \mathrm{rpm}$ mendapatkan nilai thrust sebesar 13,6 KgF berdasarkan rerata dari ketiga percobaan tersebut.Pengujian dilakukan untuk mengetahui nilai rpm, temperature spool propeller, temperature engine fin, dan thrust dari engine DLE 55 cc Single Cylinder Petrol. Pengukuran rpm dilakukan menggunakan dua sensor yang terdiri dari sensor yang telah dirancang yaitu tachometer dan sensor yang berasal dari pabrik yaitu GT Power Ignition. Berdasarkan hasil pengujian dapat disimpulkan bahwa, hasil pengukuran rpm oleh GT Power nilainya lebih tinggi dibandingkan dengan hasil pengukuran menggunakan sensor tachometer yang telah dirancang. Hal ini dipengaruhi oleh jarak pengukuran pada saat pengujian, karena berdasarkan spesifikasi tachometer yang digunakan jarak yang dianjurkan adalah $50-500 \mathrm{~mm}$ dan tidak melebihi dari spesifikasi tersebut. Adapun faktor lain yang menyebabkan perbedaan hasil pengukuran adalah, pemilihan laser dari tachometer yang disarankan dengan kualitas paling efisien dan dapat menembakkan cahaya laser dengan baik, sehingga pengukuran nilai rpm yang didapatkan lebih akurat. Kecepatan putar propeller (rpm) dapat mempengaruhi nilai dari temperature dan thrust yang akan diukur. Hubungan antara rpm dengan parameter yang lain adalah, semakin tinggi nilai rpm maka semakin tinggi nilai temperature dan juga thrust yang terukur selama pengujian. Pernyataan ini didukung dengan penelitian oleh Iriandi et al., (2016) menyatakan bahwa besarnya jumlah rpm mempengaruhi kecepatan saat engine hidup, dimana semakin besar rpm maka semakin besar juga kecepatan rate of vertical flight yang dihasilkan. Selain itu, besarnya rpm juga mempengaruhi waktu yang dibutuhkan oleh pesawat untuk mencapai ketinggian, semakin besar rpm maka semakin cepat juga waktu yang dibutuhkan untuk mencapai ketinggian.

\section{b. Hasil Pengujian Propeller Tipe Kayu 22 X 8 Chord 5 Cm}

Perhitungan rata-rata juga dilakukan pada hasil pengujian propeller tipe kayu chord 5 $\mathrm{cm}$. Hal ini dilakukan untuk memudahkan perbandingan hasil antara propeller chord 4,5 $\mathrm{cm}$ dan chord $5 \mathrm{~cm}$. Jika dibuat grafik perbandingan, maka dapat diketahui perbedaan 
antara nilai thrust dengan rpm pada propeller tipe kayu chord $5 \mathrm{~cm}$. Grafik perbandingan dapat dilihat pada Gambar 21.

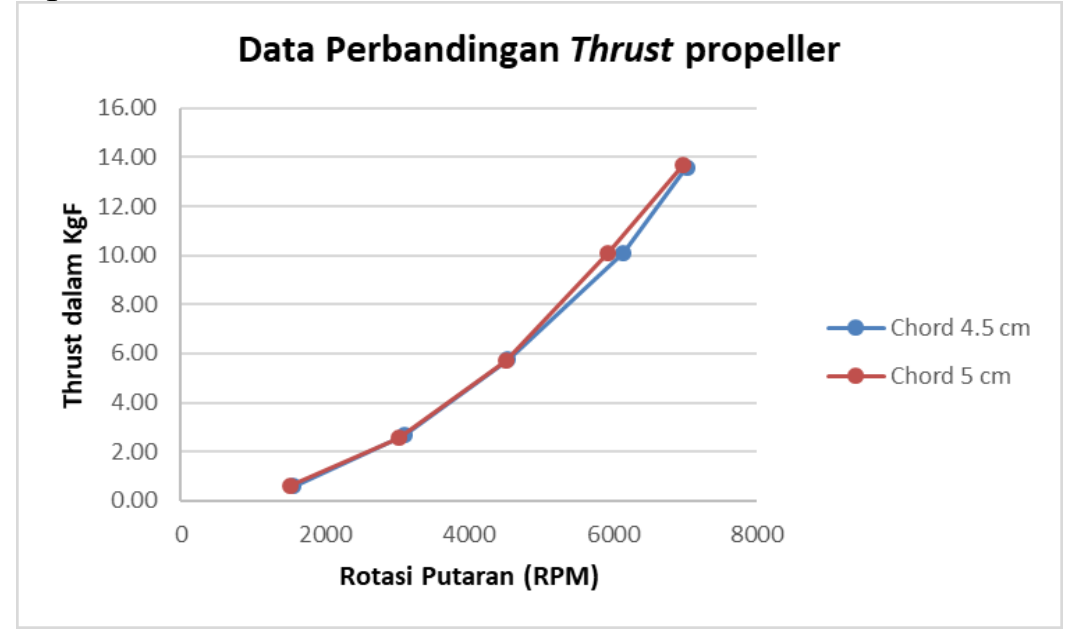

Gambar 21. Grafik Perbandingan Thrust dengan RPM pada Chord $5 \mathrm{~cm}$

Pengujian propeller tipe kayu 22 × 8 chord $5 \mathrm{~cm}$ dan chord $4,5 \mathrm{~cm}$ dilakukan di Laboratorium Nurtanio. Grafik pada Gambar 4.2 menunjukkan hasil perbandingan antara nilai thrust dengan rpm pada pengujian propeller chord $5 \mathrm{~cm}$. Berdasarkan grafik dapat diketahui bahwa, pengukuran dengan kecepatan rpm minimum menghasilkan thrust sebesar 0,62 KgF, sedangkan pada rpm maksimum menghasilkan nilai thrust sebesar 13,70 KgF.Pengukuran nilai thrust dilakukan dengan menggunakan sensor load cell yang dipasang pada meja uji. Sebelum melakukan pengujian, terlebih dahulu sensor load cell dikalibrasi menggunakan anak timbangan ukuran $1 \mathrm{Kg}$. Sensor load cell yang digunakan memiliki kapasitas $20 \mathrm{Kg}$. Sensor ini dipasang sejajar dengan dudukan engine pada meja uji, agar hasil pengukuran thrust engine yang didapat maksimal. Hasil pengukuran dari load cell akan diolah oleh amplifier HX711 dan datanya diakuisisi oleh mikrokontroller Arduino UNO untuk diolah dan ditampilkan nilainya pada LCD. Berdasarkan hasil pengukuran thrust pada chord 4,5 cm menghasilkan nilai thrust maksimum sebesar 13,60 $\mathrm{KgF}$. Sedangkan pada propeller chord $5 \mathrm{~cm}$ mendapatkan nilai thrust maksimum sebesar $13,70 \mathrm{KgF}$. Faktor yang mempengaruhi perbedaan hasil pengukuran ini adalah karena perbedaan ukuran pada airfoil propeller tersebut, semakin besar ukuran airfoil tersebut maka semakin besar juga gaya dorong yang dihasilkan. Pernyataan ini didukung dengan hasil penelitian dari Priyanto (2009) yang menjelaskan bahwa, variabel yang berpengaruh terhadap pemilihan propeller yaitu rpm, pitch, dan kualitas bahan (impor) atau lokal. Selain itu juga disebabkan oleh diameter yang lebih pendek dan posisi angle tip propeller yang lebih kecil. Semakin besar dutu pitch (blade angle) yaitu mulai 0' hingga 55' maka semakin besar pula thrust yang dihasilkan. Berdasarkan hasil pengujian diketahui bahwa nilai error yang didapatkan pada sensor load cell untuk nilai thrust dengan static thrust propeller cukup rendah sehingga perlu dilakukan adanya pengembangan pada penelitian ini.

\section{c. Validasi Hasil Pengujian RPM pada Propeller Chord 4,5 cm}

Validasi yang dilakukan pada pengujian ini hanya pada parameter rpm dan thrust yang terukur. Nilai rpm divalidasi menggunakan hasil pengukuran dari GT Power Ignition terhadap hasil pengukuran rpm oleh tachometer. Perhitungan margin error dilakukan dengan menghitung selisih nilai antara data hasil pengukuran GT power dengan tachometer, dan dibagi dengan nilai GT Power. Semakin kecil nilai margin error yang didapatkan, maka akan semakin akurat pengujian yang dilakukan. Pengujian dikatakan 
baik apabila nilai margin error yang didapatkan kurang dari 2\%. Jika dibuat grafik perbandingan, maka akan terlihat perbedaan antara nilai margin error dengan rpm pada propeller tipe kayu chord 4,5 cm. Grafik perbandingan gaya dapat dilihat pada Gambar 22.

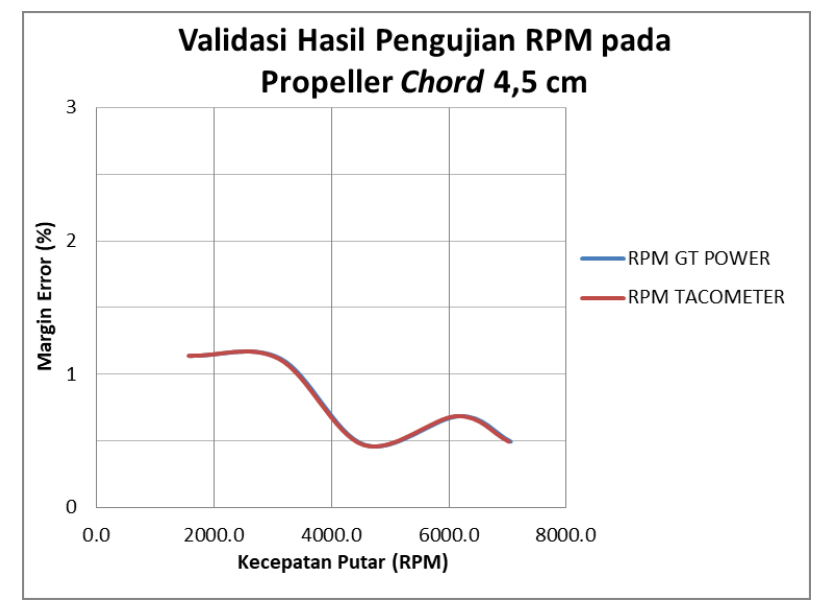

Gambar 22. Grafik Margin error Hasil Pengujian Propeller Chord 4,5 cm

Berdasarkan grafik yang ditunjukkan pada Gambar 22. dapat diketahui bahwa hasil pengukuran rpm oleh GT power maupun tachometer menghasilkan nilai yang hampir sama, sehingga kedua garisnya berhimpitan. Perhitungan margin error pada kecepatan minimum $1500 \mathrm{rpm}$ menghasilkan margin error sebesar 1,139\%, sedangkan pada kecepatan maksimum $7000 \mathrm{rpm}$ menghasilkan margin error sebesar 0,495\%. Nilai margin error terbesar terjadi pada kecepatan 1500, sedangkan nilai margin error terkecil terjadi pada titik setting 4500 yaitu $0,470 \%$. Faktor yang mempengaruhi hasil pengukuran ini adalah karena pemilihan laser dari tachometer. Kualitas laser yang baik akan menghasilkan data dengan nilai error yang kecil. Kualitas laser dapat diketahui dari pantulan cahaya dari tachometer yang berfungsi untuk mengukur rpm dari propeller ketika berputar. Dari rata rata error yang dihasilkan dapat diketahui bahwa, alat uji yaitu sistem sensor mempunyai akurasi yang baik, dikarenakan rata-rata error yang didapat kurang dari $2 \%$.

\section{d. Validasi Hasil Pengujian RPM pada Propeller Chord $5 \mathrm{~cm}$}

Validasi dilakukan pada hasil pengujian propeller tipe kayu chord $5 \mathrm{~cm}$ yang ditunjukkan pada Tabel 4.10. Validasi dilakukan pada nilai rpm yang terukur. Jika dibuat grafik perbandingan, maka akan terlihat perbedaan antara nilai margin error dengan rpm pada propeller tipe kayu chord $5 \mathrm{~cm}$. Grafik perbandingan gaya dapat dilihat pada Gambar 23. 


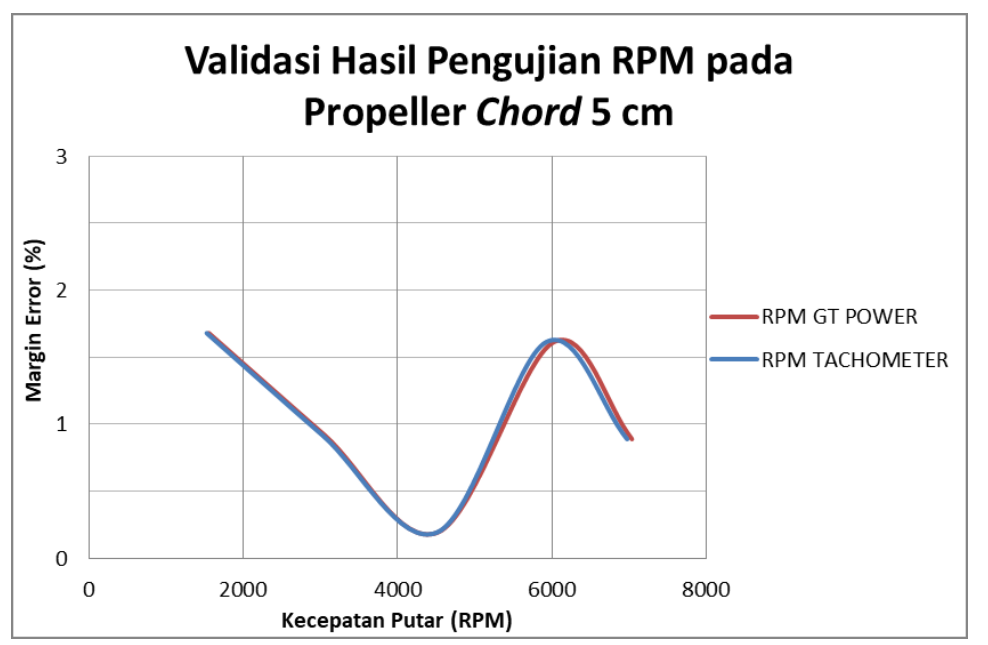

Gambar 23. Grafik Margin error Hasil Pengujian Propeller Chord $5 \mathrm{~cm}$

Dari hasil perbandingan error pada alat ukur, dapat dilihat pada grafik Gambar 23. diketahui bahwa hasil pengukuran rpm oleh GT power dan tachometer pada propeller dengan chord $5 \mathrm{~cm}$ menghasilkan nilai yang hampir sama sehingga kedua garisnya berhimpitan. Berdasarkan hasil perhitungan diketahui bahwa nilai error maksimum terjadi pada kecepatan $1500 \mathrm{rpm}$ dengan nilai 1,679\% dan minimum pada kecepatan $4500 \mathrm{rpm}$ dengan nilai $0,191 \%$. Dari pembacaan sensor rpm pada propeller tipe ini tidak jauh berbeda nilai rpm dengan tipe sebelumnya, hal ini disebabkan karena jarak pengukuran sensor dengan propeller tidak melebihi spesifikasi dari sensor tersebut. Nilai masingmasing dari kedua sensor tersebut dapat dijadikan sebagai acuan untuk perbandingan menentukan rpm dari propeller tersebut.Validasi hasil pengujian pada propeller chord 4,5 $\mathrm{cm}$ menghasilkan nilai kesalahan maksimum pada rpm 1500 yaitu 1,139\% dengan ratarata margin error sebesar $0,782 \%$. Hasil validasi untuk propeller chord 5 menunjukkan bahwa, margin error maksimum terjadi saat rpm bernilai 1500 yaitu sebesar 1,679\%, dengan rata-rata kesalahan sebesar $1,058 \%$. Dari rata rata margin error yang dihasilkan dapat diketahui bahwa, alat uji yaitu sistem sensor mempunyai akurasi yang baik, dikarenakan rata-rata margin error yang didapat kurang dari $2 \%$. Perawatan dan pemilihan laser tachometer juga harus dilakukan dengan berkala untuk meningkatkan kemampuan pengukuran rpm oleh tachometer, sesuai dengan hasil penelitian oleh Enny (2019) yang mengatakan bahwa, alat tachometer laser dapat melakukan pengukuran dari jarak jauh yaitu bekerja dengan sensor cahaya yang sangat sensitif terhadap elemen berputar. Maka dari itu alat harus dirawat dan diperbaiki secara teratur untuk mendapatkan nilai dari setiap rpm yang akan diukur. Apabila terjadi kerusakan, kegiatan perawatan yang dilakukan adalah penggatian laser dari tachometer tersebut untuk mendapatkan cahaya laser yang baik dan untuk mengurangi margin error pada saat digunakan. Dengan adanya perawatan dan pemakaian yang tepat diharapkan bahwa alat tachometer laser agar dapat berfungsi dengan baik dalam waktu yang lama.

\section{KESIMPULAN}

Sistem sensor untuk pengukuran propeller test bench terdiri dari rangkaian Arduino UNO sebagai mikrokontoller, load cell sebagai sensor pengukur thrust, tachometer sebagai pengukur nilai rpm, dan thermostat sebagai pengukur tempratur dari engine fin dan spool propeller. Perbandingan pengukuran nilai thrust dengan static thrust calculator didapatkan hasil thrust pada propeller chord 4,5 cm thrust maksimum sebesar $13,60 \mathrm{KgF}$ dan minimum sebesar 0.60 $\mathrm{KgF}$ sedangkan pada propeller chord $5 \mathrm{~cm}$ didapatkan hasil thrust maksimum sebesar 13,70 $\mathrm{KgF}$ dan minimum sebesar $0,62 \mathrm{KgF}$. 


\section{DAFTAR PUSTAKA}

[1] Arifin, S.R., Anggraeni D., Rahmadi A., Sumarna E., 2014. Engine and Propeller Selection for Propulsion System LAPAN Surveillance UAV-05 using Static Thrust Calculation and Test. Proceedings ISAST. Indonesia. Vol. 2: 41-50.

[2] Fikri, M. A., Erwanto, D., dan Yuliana, D. E. 2018. Rancang Bangun Alat Prediksi Kondisi Tubuh Ideal Menggunakan Metode Fuzzy Logic Sugeno. Sistem KendaliTenaga-Elektronika-Telekomunikasi-Komputer, Vol. 7 (1); 169 - 181.

[3] Gustomo, B. 2015. Pengenalan Arduino Dan Pemrogrammannya. Informatika Bandung, Bandung.

[4] Harsoyo, I. T., Nugroho, A. K., dan Nuriman. 2019. Rancang Bangun Tachometer Digital Berbasis Arduino Dilengkapi Charging dan Mode Penyimpan Data. Elektrikal, Vol. 11 (2): 6-11.

[5] Hilal, A., dan Manan, S. 2012. Pemanfaatan Motor Servo sebagai Penggerak CCTV untuk Melihat Alat-Alat Monitor dan Kondisi Pasien di Ruang ICU. Gema Teknologi, Vol. 12 (2).

[6] Kadir, A. 2012. Panduan Praktis Mempelajari Aplikasi Mikrokontroler dan Pemrogramannya Menggunakan Arduino. Penerbit Andi, Yogyakarta.

[7] Khakim, A. L. 2015. Rancang Bangun Alat Timbang Digital Berbasis AVR Tipe Atmega32. Tugas Akhir. Semarang: Universitas Negeri Semarang.

[8] Manege, P. M. N., Allo, E. K., dan Bahrun. 2017. Rancang Bangun Timbangan Digital dengan Kapasitas $20 \mathrm{Kg}$ Berbasis Microcontroller ATMega8535. E-Journal Teknik Elektro dan Komputer Vol. 6 (1).

[9] Nugraha, D. A. 2017. Timbangan Gantung Digital Dengan Sensor HX711 (Load Cell) Berbasis Arduino UNO. Universitas Sumatra Utara.

[10] Rifan, M. 2016. Pembuatan Alat Uji Propeller (Propeller Test Bench). Skripsi Institut Teknologi Dirgantara Adisutjipto.

[11] Saputra, M. dan Hakim, I. 2016. Maintenance Propeller Hartzell pada Pesawat Cessna 172. Jurnal Mekanova, Vol. 2 (3): 158- 166.

[12] Setyadewi, I. T. dan Nugroho, Y. A. 2018. Analisis Pemilihan Propeller Mesin Pesawat Tanpa Awak LSU 03. Majalah Sains dan Teknologi Dirgantara, Vol. 13 (1): 23-30.

[13] Islami dan Hartono. 2020. Analisis Cara Kerja Sensor Ultrasonic dan Motor Servo menggunakan Mikrokontroler Arduino UNO untuk Pengusir Hama Disawah. Skripsi Universitas Bandar Lampung. 